\title{
EVALUATION OF N EFFICIENCY USING PRILLED UREA AND UREA SUPER GRANULES IN T. AMAN RICE
}

\author{
J Hussain ${ }^{1}$, M Salim ${ }^{2},{ }^{*}$ M A Siddique ${ }^{3}$, M Khatun $^{4}$ and S Islam ${ }^{5}$ \\ ${ }^{1}$ HarvestPlus-Bangladesh, Barisal; ${ }^{2}$ Department of Agronomy, Bangladesh Agricultural University, Mymensingh \\ ${ }^{3}$ Genetic Resources and Seed Division, Bangladesh Rice Research Institute, Gazipur \\ ${ }^{4}$ Janata Bank Limited, Barisal; ${ }^{5}$ Bangladesh Agricultural Development Corporation, Mymensingh \\ *Corresponding Author: mabs198401@yahoo.com
}

Key words: Nitrogen use efficiency, Prilled urea, Urea super granule, transplant aman rice

\begin{abstract}
An experiment was conducted at the Experimental field of Department of Agronomy, Bangladesh Agricultural University, Mymensingh, during June to December 2007 to evaluate the nitrogen use efficiency of transplant aman rice using prilled urea (PU) and urea super granule (USG). Three rice varieties (BR11, BRRI dhan30 and BRRI dhan39) were compared at three doses of nitrogen, i.e., PU@125 kg N ha-1, USG @170 kg N ha-1 and USG @ $70 \mathrm{~kg} \mathrm{~N}^{-1} \mathrm{~N}^{-1}$ in a Randomized Complete Block (RCB) design with three replications. USG each weighing $1 \mathrm{~g}$ and $2.6 \mathrm{~g}$ were placed manually at the depth of $8-10 \mathrm{~cm}$ in the middle of four hills in alternate rows at 12 days after transplanting and PU applied in split applications. The rice var. BR11 at USG @70 kg $\mathrm{N}$ ha ${ }^{-1}$ has produced the maximum grain yield $\left(4.75 \mathrm{t} \mathrm{ha}^{-1}\right)$ which was statistically identical to BRRI dhan30 at USG @ $70 \mathrm{~kg} \mathrm{~N} \mathrm{ha}^{-1}\left(1 \mathrm{~g} \mathrm{pellet}^{-1}\right)$. The highest nitrogen use efficiency, partial factor productivity and marginal rate of return (1966\%) were recorded from the treatment of BR11 at USG @ $70 \mathrm{~kg} \mathrm{~N} \mathrm{ha}^{-1}$.
\end{abstract}

\section{Introduction}

Farmers of Bangladesh generally apply nitrogenous fertilizers in several split applications and the efficiency of applied nitrogen uptake by the rice plant ranges between 25 and 35\% (Singh and Yadav, 1985). The applied nitrogen is lost due to leaching, surface run-off, $\mathrm{NH}_{3}$ volatilization, denitrification and other processes; consequently $\mathrm{N}$ fertilizer use efficiency decreases. There are different types of nitrogenous fertilizers available in Bangladesh. Urea super granules (USG) are one of them and urea super granule that can be applied to the root zone of the rice plants at $8-10 \mathrm{~cm}$ depth of soil (reduced zone of rice soil), which can save 30\% nitrogen compared to prilled urea. It increases absorption rate, improves soil health and ultimately increases rice yield (Savant et al., 1991). Deep placement of USG effectively increases $\mathrm{N}$ use efficiency (31.7\%) compared to conventionally applied prilled urea (Jaiswal and Singh, 2001). Therefore, it is essential to evaluate the response of high yielding rice varieties such as to different levels of urea super granules.

\section{Materials and Methods}

The experiment was conducted at the Agronomy Field Laboratory, Bangladesh Agricultural University, Mymensingh during aman season, 2007. The three high yielding rice varieties namely, BR11 $\left(\mathrm{V}_{1}\right)$, BRRI dhan30 $\left(\mathrm{V}_{2}\right)$, BRRI dhan39 $\left(\mathrm{V}_{3}\right)$ and three sources of nitrogen namely prilled urea at the rate of $125 \mathrm{~kg} \mathrm{~N}^{-1}\left(\mathrm{~N}_{1}\right)$, One pellet of USG (weight $2.6 \mathrm{~g}$ ) per 4 hills $\cong 170 \mathrm{~kg} \mathrm{~N} \mathrm{ha}-1\left(\mathrm{~N}_{2}\right)$, One pellet of USG (weight $1 \mathrm{~g}$ ) per 4 hills $\cong 70 \mathrm{~kg} \mathrm{~N} \mathrm{ha}^{-1}\left(\mathrm{~N}_{3}\right)$ were 
Hussain et al.

laid out in a factorial randomized complete block design (RCBD) with three replicates. The unit plot size was $10 \mathrm{~m}^{2}(4.0 \mathrm{~m} \times 2.5 \mathrm{~m})$. At the time of final land preparation, $51.25 \mathrm{~kg}$ Triple Super Phosphate (TSP), $60 \mathrm{~kg}$ Muriate of Potash (MP), $33.75 \mathrm{~kg}$ Gypsum and $5 \mathrm{~kg}$ Zinc Sulphate ha ${ }^{-1}$ were applied. Nitrogen was applied according to the treatments. Thirty- day- old seedlings were transplanted at the rate of 3 seedlings hill-1 on the well-puddled plots on $13^{\text {th }}$ August 2007 maintaining $25 \mathrm{~cm}$ x $15 \mathrm{~cm}$ spacing. After 12 days of transplanting, one pellet of different sizes $(2.6 \mathrm{~g}$ and $1 \mathrm{~g}$ ) USG as a source of nitrogen were placed manually in the root zone at $8-10 \mathrm{~cm}$ depth at the centre of four hills of two adjacent rows. Appropriate plant protection measures and management practices were followed throughout the growing period.. The grain yield was adjusted to $14 \%$ moisture content. The Agronomic Efficiency of Nitrogen (AEN) was calculated as additional grain yield over the control per kilogram $\mathrm{N}$ applied with the following formula:

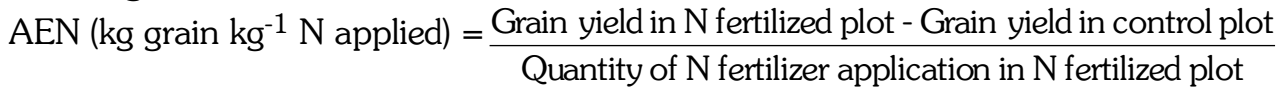

The Partial Factor Productivity of Nitrogen (PFP-N) was calculated with the following formula:

PFP-N $=\frac{\text { Total grain yield }\left(\mathrm{kg} \mathrm{ha}^{-1}\right)}{\text { Amount of applied } \mathrm{N}\left(\mathrm{kg} \mathrm{ha}^{-1}\right)}$

Marginal Rate of Return (MRR) was calculated for the treatment $\mathrm{X}_{\mathrm{i}}$ as

$\mathrm{MRR}=\frac{\text { Marginal gross margin of } \mathrm{X}_{\mathrm{i}}}{\text { Marginal cost that vary of } \mathrm{X}_{\mathrm{i}}}$

Data were analyzed and were separated according to Duncan's Multiple Range test (DMRT).

\section{Results and Discussion}

Interaction between variety and nitrogen level was significant for number of tiller, panicle, grains per panicle and sterile spikelets per panicle. There was no significant difference in plant height (Table 1). The results are in agreement with the findings of Rahman (2003) who observed that different levels of USG did not affect the plant height. The variety BR11 grown with $70 \mathrm{~kg} \mathrm{~N}$ ha-1 as USG produced the highest number of tillers/ sq. meter (408.8) and the lowest from BRRI dhan39 with PU (Table 1). The higher number of tillers resulted at $70 \mathrm{~kg} \mathrm{~N}$ $\mathrm{ha}^{-1}$ as USG might be due to increased availability of nitrogen that played a vital role in cell division. The results differ with the findings of Hasan (2007) who recorded the increased number of tiller/sq. $\mathrm{m}$ with the increased $\mathrm{N}$ level as USG.

Table 1. Effect of interaction between variety and source of nitrogen on crop characters of $\mathrm{T}$. aman rice.

\begin{tabular}{c|c|c|c}
\hline Variety x Nitrogen & Plant height $(\mathrm{cm})$ & Tillers no./sq.meter & Panicle no./sq. meter \\
\hline $\mathrm{V}_{1} \mathrm{~N}_{1}$ & 97.03 & $347.47 \mathrm{~b}$ & $230.93 \mathrm{c}$ \\
$\mathrm{V}_{1} \mathrm{~N}_{2}$ & 95.86 & $288.00 \mathrm{~d}$ & $152.27 \mathrm{~d}$ \\
$\mathrm{~V}_{1} \mathrm{~N}_{3}$ & 99.66 & $408.8 \mathrm{a}$ & $304.8 \mathrm{a}$ \\
$\mathrm{V}_{2} \mathrm{~N}_{1}$ & 97.30 & $284.27 \mathrm{~d}$ & $172.27 \mathrm{~d}$ \\
$\mathrm{~V}_{2} \mathrm{~N}_{2}$ & 95.60 & $336.00 \mathrm{bc}$ & $236.27 \mathrm{c}$ \\
$\mathrm{V}_{2} \mathrm{~N}_{3}$ & 97.80 & $360.8 \mathrm{~b}$ & $284.27 \mathrm{~b}$ \\
$\mathrm{~V}_{3} \mathrm{~N}_{1}$ & 101.23 & $270.13 \mathrm{~d}$ & $163.47 \mathrm{~d}$ \\
$\mathrm{~V}_{3} \mathrm{~N}_{2}$ & 99.66 & $321.6 \mathrm{c}$ & $197.33 \mathrm{~cd}$ \\
$\mathrm{~V}_{3} \mathrm{~N}_{3}$ & 102.23 & $344.00 \mathrm{~b}$ & $228.27 \mathrm{c}$ \\
$\mathrm{CV}(\%)$ & 2.58 & 6.85 & 4.60 \\
\hline
\end{tabular}

In a column, figures with same letter or without letter do not differ significantly as per DMRT

$\mathrm{V}_{1}=\mathrm{BR} 11, \mathrm{~V}_{2}=\mathrm{BRRI}$ dhan30, $\mathrm{V}_{3}=\mathrm{BRRI}$ dhan39, $\mathrm{N}_{1}=125 \mathrm{~kg} \mathrm{~N} \mathrm{ha}{ }^{-1}$ (PU/No pellet of USG), $\mathrm{N}_{2}=\mathrm{USG}_{\text {(170 }}$

$\left.\mathrm{kg} \mathrm{N} \mathrm{ha}{ }^{-1}\right), \mathrm{N}_{3}=$ USG $\left(70 \mathrm{~kg} \mathrm{~N} \mathrm{ha}^{-1}\right)$ 
Interaction between variety and nitrogen was found significant in panicles/ sq.meter where the highest number of panicle/sq.meter (304.8) was from BR11 at $70 \mathrm{~kg} \mathrm{~N}^{-1}$ as USG while lowest panicles (152.27) was produced by same variety at $170 \mathrm{~kg} \mathrm{~N}^{-1}$ as USG.

Application of $\mathrm{N}$ fertilizers significantly increased the number of grains per panicle where variety BR11 at $70 \mathrm{~kg} \mathrm{~N}$ ha $^{-1}$ as USG produced highest number of grains per panicle (148.9) while lowest number of grains per panicle (101.95) from the BRRI dhan30 at PU. Availability of more nitrogen from USG during grain formation and development that contributed to higher number of grains per panicle. These results are in agreement with the findings of Thakur (1991).

The interaction between variety and dose of nitrogen on number of sterile spikelets per panicle was significant where BRRI dhan39 produced the highest number of sterile spikelets per panicle (35.90) when $\mathrm{N}$ was applied in the form of prilled urea while the variety BRRI dhan30 at $70 \mathrm{~kg} \mathrm{~N} \mathrm{ha}{ }^{-1}$ as USG produced the lowest number of sterile spikelets per panicle (14.3).

Application of nitrogen had no significant effect on the 1000-grain weight (Table 2). The results are in agreement with the findings of Hasan (2007) who also observed that the different levels of USG did not affect the 1000-grain weight.

Grain yield was not significantly influenced by the interaction between variety and nitrogen dose but maximum grain yield (4.75 $\mathrm{t} \mathrm{ha}^{-1}$ ) was recorded in BR11 with USG @ $70 \mathrm{~kg} \mathrm{~N}^{-1}$ and the lowest (3.25 t ha-1) in BRRI dhan30 with PU. It was also noted that all the rice varieties responded in the same way to the different nitrogen doses. Similar trend was followed in case of straw yield and harvest index. Harvest index ranged from 44.07 to $48.39 \%$ (Table 2).

Table 2. Effect of interaction between variety and nitrogen source on yield contributing characters and yield of $T$. aman rice.

\begin{tabular}{c|c|c|c|c|c|c}
\hline $\begin{array}{c}\text { Variety x } \\
\text { Nitrogen }\end{array}$ & $\begin{array}{c}\text { Grains } \\
\text { panicle } \\
\text { (no.) }\end{array}$ & $\begin{array}{c}\text { Sterile } \\
\text { spikelets } \\
\text { panicle } \\
\text { (no.) }\end{array}$ & $\begin{array}{c}1000- \\
\text { grain } \\
\text { weight } \\
\text { (g) }\end{array}$ & $\begin{array}{c}\text { Grain } \\
\text { yield } \\
\text { (t ha-1) }\end{array}$ & $\begin{array}{c}\text { Straw } \\
\text { yield } \\
\text { (t ha-1) }\end{array}$ & $\begin{array}{c}\text { Harvest } \\
\text { Index } \\
(\%)\end{array}$ \\
\hline $\mathrm{V}_{1} \mathrm{~N}_{1}$ & $140.91 \mathrm{~b}$ & $23.78 \mathrm{bc}$ & 24.82 & 3.58 & 4.16 & 46.26 \\
$\mathrm{~V}_{1} \mathrm{~N}_{2}$ & $126.55 \mathrm{c}$ & $25.77 \mathrm{~b}$ & 24.52 & 3.83 & 4.83 & 44.23 \\
$\mathrm{~V}_{1} \mathrm{~N}_{3}$ & $148.89 \mathrm{a}$ & $21.00 \mathrm{c}$ & 24.98 & 4.75 & 5.08 & 48.39 \\
$\mathrm{~V}_{2} \mathrm{~N}_{1}$ & $101.95 e$ & $15.39 \mathrm{~d}$ & 21.39 & 3.25 & 4.08 & 44.28 \\
$\mathrm{~V}_{2} \mathrm{~N}_{2}$ & $114.77 \mathrm{~d}$ & $21.10 \mathrm{c}$ & 21.91 & 3.33 & 4.25 & 44.07 \\
$\mathrm{~V}_{2} \mathrm{~N}_{3}$ & $132.06 \mathrm{c}$ & $14.33 \mathrm{~d}$ & 22.29 & 4.08 & 4.83 & 45.84 \\
$\mathrm{~V}_{3} \mathrm{~N}_{1}$ & $130.17 \mathrm{c}$ & $35.90 \mathrm{a}$ & 24.07 & 3.41 & 3.91 & 46.62 \\
$\mathrm{~V}_{3} \mathrm{~N}_{2}$ & $142.21 \mathrm{ab}$ & $27.20 \mathrm{~b}$ & 24.37 & 3.5 & 4.33 & 44.58 \\
$\mathrm{~V}_{3} \mathrm{~N}_{3}$ & $147.64 \mathrm{ab}$ & $23.88 \mathrm{bc}$ & 24.35 & 3.91 & 4.58 & 46.18 \\
$\mathrm{CV}(\%)$ & 3.21 & 8.37 & 1.14 & 6.94 & 8.36 & 5.07 \\
\hline
\end{tabular}

In a column, figures with same letter or without letter do not differ significantly as per DMRT.

Two $N$ use efficiency indicators were used i.e. agronomic efficiency of $N(A E N)$ and partial factor productivity of $\mathrm{N}$ (PFP-N).

From Table 3, it was evident that when $\mathrm{N}$ was applied as USG at $170 \mathrm{~kg} \mathrm{~N} \mathrm{ha}^{-1}$, grain yield was less and agronomic efficiency of $\mathrm{N}(\mathrm{AEN})$ was found minimum $(1.47,0.47$ and $0.52 \mathrm{~kg}$ grain / kg N respectively) for all varieties while when $\mathrm{N}$ was applied at $70 \mathrm{~kg} \mathrm{~N} \mathrm{ha}^{-1}$ as USG 
Hussain et al.

AEN were found maximum $(16.71,11.86$ and $7.14 \mathrm{~kg}$ grain $/ \mathrm{kg} \mathrm{N}$, with all varieties (BR11, BRRI dhan30 and BRRI dhan39 respectively). The results are in agreement with the findings of Siddika (2007) who observed that, $\mathrm{N}$ use efficiency was higher with USG as compared to prilled urea.

Table 3. Effect of N (PU, USG) on grain yield, AEN, and PFP- N management techniques-

\begin{tabular}{c|c|c|c|c}
\hline Treatments & $\begin{array}{c}\text { Applied N as urea } \\
\left(\mathrm{kg} \mathrm{ha}^{-1}\right)\end{array}$ & $\begin{array}{c}\text { Grain yield } \\
\left(\mathrm{t} \mathrm{ha}^{-1}\right)\end{array}$ & $\begin{array}{c}\text { Agronomic } \\
\text { efficiency of } \mathrm{N} \\
\text { (AEN) }\end{array}$ & $\begin{array}{c}\text { Partial factor } \\
\text { productivity of } \mathrm{N} \\
\text { (PFP-N) }\end{array}$ \\
\hline $\mathrm{V}_{1} \mathrm{~N}_{1}$ & 125 & 3.58 & 00 & 28.64 \\
$\mathrm{~V}_{1} \mathrm{~N}_{2}$ & 170 & 3.83 & 1.47 & 22.53 \\
$\mathrm{~V}_{1} \mathrm{~N}_{3}$ & 70 & 4.75 & 16.71 & 67.86 \\
$\mathrm{~V}_{2} \mathrm{~N}_{1}$ & 125 & 3.25 & 0 & 26.0 \\
$\mathrm{~V}_{2} \mathrm{~N}_{2}$ & 170 & 3.33 & 0.47 & 19.59 \\
$\mathrm{~V}_{2} \mathrm{~N}_{3}$ & 70 & 4.08 & 11.86 & 58.29 \\
$\mathrm{~V}_{3} \mathrm{~N}_{1}$ & 125 & 3.41 & 00 & 27.28 \\
$\mathrm{~V}_{3} \mathrm{~N}_{2}$ & 170 & 3.50 & 0.52 & 20.59 \\
$\mathrm{~V}_{3} \mathrm{~N}_{3}$ & 70 & 3.91 & 7.14 & 55.86 \\
\hline
\end{tabular}

It was also observed that when $\mathrm{N}$ was applied as USG at $170 \mathrm{~kg} \mathrm{~N} \mathrm{ha}{ }^{-1}$ poor performance in respect of partial factor productivity of $\mathrm{N}$ (PFP-N) were 22.53, 19.59 and 20.59, with rice varieties BR11, BRRI dhan30 and BRRI dhan39 respectively. However, with the use of USG at $70 \mathrm{~kg} \mathrm{~N}$ ha-1 PFP-N was recorded to be highest in all varieties $(67.86,58.29$ and 55.86 respectively). The prilled urea performed the lowest in respect of PFP-N.

Dominance analysis: Six treatments $\mathrm{V}_{3} \mathrm{~N}_{3}, \mathrm{~V}_{2} \mathrm{~N}_{3}, \mathrm{~V}_{3} \mathrm{~N}_{1}, \mathrm{~V}_{2} \mathrm{~N}_{1}, \mathrm{~V}_{3} \mathrm{~N}_{2}$ and $\mathrm{V}_{1} \mathrm{~N}_{2}$ were found cost dominated, where cost is more but gross margin is less than that of many other treatments (Table 4)

Table 4. Dominance analysis

\begin{tabular}{c|c|c|c}
\hline Gross margin & Treatment & $\begin{array}{c}\text { Variable Cost } \\
\left(\text { Tk.ha }{ }^{-1}\right)\end{array}$ & Cost dominance \\
\hline 68253 & $\mathrm{~V}_{3} \mathrm{~N}_{3}$ & 2127 & $*$ \\
71313 & $\mathrm{~V}_{2} \mathrm{~N}_{3}$ & 2127 & $*$ \\
83373 & $\mathrm{~V}_{1} \mathrm{~N}_{3}$ & 2127 & $*$ \\
58125 & $\mathrm{~V}_{3} \mathrm{~N}_{1}$ & 3255 & $*$ \\
55245 & $\mathrm{~V}_{2} \mathrm{~N}_{1}$ & 3255 & $*$ \\
61185 & $\mathrm{~V}_{1} \mathrm{~N}_{1}$ & 3255 & $*$ \\
57835 & $\mathrm{~V}_{3} \mathrm{~N}_{2}$ & 5165 & $*$ \\
54775 & $\mathrm{~V}_{2} \mathrm{~N}_{2}$ & 5165 & $*$ \\
63775 & $\mathrm{~V}_{1} \mathrm{~N}_{2}$ & 5165 & \\
\hline
\end{tabular}

Marginal analysis: The marginal analysis of undominated cost of treatments is shown in table 5. The treatment $\mathrm{V}_{1} \mathrm{~N}_{3}$ showed the highest MRR (1966\%) indicating that the fertilizer $70 \mathrm{~kg} \mathrm{~N}$ ( USG) dose if applied in BR11 production during T. Aman season gives the highest marginal rate of return. 
Evaluation of N Efficiency Using Prilled Urea and Urea Super Granules in T.Aman Rice

Table 5. Marginal analysis of undominated fertilizer response data

\begin{tabular}{c|c|c|c|c|c}
\hline $\begin{array}{c}\text { Gross } \\
\text { margin }\end{array}$ & Treatment & $\begin{array}{c}\text { Variable Cost } \\
\left(\text { Tk.ha }^{-1}\right)\end{array}$ & $\begin{array}{c}\text { Marginal cost } \\
\left(\text { Tk.ha }^{-1}\right)\end{array}$ & $\begin{array}{c}\text { Marginal Gross } \\
\text { Margin (Tk.ha }\end{array}$ & $\begin{array}{c}\text { Marginal Rate } \\
\text { of Return } \\
\text { (MRR) (\%) }\end{array}$ \\
\hline 83373 & V1N3 & 2126 & 1128.4 & 22188.4 & 1966 \\
61185 & V1N1 & 3255 & 1909.6 & 2590.4 & 136 \\
63775 & V1N2 & 5164 & 0 & 0 & 0 \\
\hline
\end{tabular}

According to the results of the present study maximum utilization of $\mathrm{N}$ is possible with the application of proper dose of N as USG. If the dose of N as USG is higher, yield is reduced. It can be concluded that, USG at $70 \mathrm{~kg} \mathrm{~N}$ ha $^{-1}$ can be used to achieve better nitrogen use efficiency and higher yields than PU with high yielding rice varieties.

\section{Conclusion}

From all treatment combinations it is clear that USG @ $70 \mathrm{~kg} \mathrm{~N}^{-1}$ produced more grain yield compared with USG @170 kg N ha-1 and prilled urea. Nitrogen use efficiency, partial factor productivity and marginal rate of return to capital were highest at USG @ $70 \mathrm{~kg} \mathrm{~N} \mathrm{ha}^{-1}$ compared to USG @ $170 \mathrm{~kg} \mathrm{~N} h a^{-1}$ and prilled urea. So, the present $\mathrm{N}$ fertilizer recommendation of USG would be $70 \mathrm{~kg} \mathrm{~N}$ ha-1 to optimize yield, rate of return and $\mathrm{N}$ use efficiency of rice varieties BR11, BRRI dhan30 and BRRI dhan39.

\section{References}

Hasan, S.M. 2007. Effect of level of urea supergranules on the performance of T. aman rice. M. Sc. Ag. Thesis in Agronomy, BAU, Mymensingh.

Jaiswal, V.P. and G.R. Singh. 2001. Performance of urea supergranule and prilled urea under different planting methods in irrigated rice (Oryza sativa). Indian J. of Agric. Sci. 71 (3): $187-189$.

Rahman, M.A. 2003. Effect of levels of urea supergranules and depth of placement on the growth and yield of transplant aman rice. MS (Ag.) Thesis, Dept. Agron., Bangladesh Agril, Univ., Mymensingh. $100 \mathrm{P}$.

Savant, N.K., S.S. Dhane and S.C. Talashikar. 1991. Fertilizer News. Intl. Fert. Dev. Centre. Muscle, Shoals, Alabama, USA. 36(3): 19-25.

Siddika, N. 2007. Effect of nitrogen management with prilled urea, urea supergranule and leaf color chart on the performance of transplant aman rice (cv., BRRI dhan41). M.S. Ag. Thesis in Agronomy, BAU, Mymensingh.

Singh, M. and D.S. Yadav. 1985. Nitrogen use efficiency in rice. Fert. Newsl. 32: 17- 23.

Thakur, R.B. 1991. Relative efficiency of prilled urea and modified urea fertilizer on rainfed low land rice. Indian J. Agron. 36 (1): 87-90. 